\title{
A localização em jogo na tradução de games
}

\section{Game localization in game translation}

\section{Gleiton Malta* Luiz Gustavo Nogueira Barcelos}

Resumo: Inserido no campo disciplinar dos Estudos da Tradução, especificamente em seu ramo descritivo orientado ao produto tradutório, este estudo analisa a tradução das falas (dublagem e legenda) do jogo Overwatch, buscando traços de localização. Ademais, buscou-se comparar a tradução do texto fonte em inglês para o espanhol latino e para o português do Brasil. Metodologicamente, o material linguístico do jogo foi extraído nos três idiomas, transcrito e depurado, configurando-se em um corpus customizado, paralelo, multilíngue e unidirecional. Os dados revelam que o corpus de em inglês é maior e mais rico lexicalmente que os subcorpora do português e do espanhol, bem como a versão brasileira é maior e mais rica lexicalmente que a versão em espanhol. Igualmente, pôde-se comprovar que a versão brasileira localiza mais o conteúdo linguístico que a versão em espanhol.

Palavras-chave. Tradução de games; localização; Estudos da tradução baseado em corpus

Abstract: Inserted in the discipline of Translation Studies, specifically in its descriptive branch oriented to the translation product, this study analyzes the translation of the speeches (dubbing and legend) of the game Overwatch, looking for characteristics of localization. In addition, we tried to compare the translation of the source text in English into Latin Spanish and into Brazilian Portuguese. Methodologically, the linguistic material of the game was extracted in the three languages, transcribed and debugged, being configured in a customized, parallel, multilingual and unidirectional corpus. The data show that the English corpus is larger and richer lexically than the subcorpora of Portuguese and Spanish. The Brazilian version is larger and more lexically rich than the Spanish version. Futhermore, it was verified that the Brazilian version localizes more the linguistic content than the Spanish version.

\footnotetext{
* Doutor em Estudos Linguísticos com ênfase em Estudos da Tradução pela Universidade Federal de Minas Gerais, mestre em Linguística Aplicada pela Universidade de Brasília e docente do curso de bacharelado em Tradução Espanhol e do Programa de Pós-graduação em Estudos da Tradução (Postrad) desta mesma universidade. E-mail: gleitonmalta@gmail.com.

Bacharel em Tradução espanhol pela UnB e mestrando no Programa de Pós-=graduação em Estudos da Tradução (Postrad - UnB). E-mail: barcelos_gustavo@hotmail.com.
} 
Keywords: Translation of games, Localization; Corpus-based translations Studies

\section{Introdução}

A tradução de games é uma área em expansão ${ }^{1}$. Tal expansão traz consigo um campo fértil para pesquisadores da área dos Estudos da Tradução. Com a entrada no país de grandes empresas do mercado de games como a Sony, Microsoft e Nintendo do Brasil, o cenário de tradução, legendagem e dublagem para o português vem ganhando espaço. Eventos como o GameWorld, realizado em São Paulo, é uma das provas do interesse de grandes empresas pelo mercado brasileiro de games ${ }^{2}$.

Tamanha diversidade de serviços e produtos traz consigo a necessidade de se refletir, teoricamente, sobre a praxis implementada nesse tipo específico de tradução. Um dos pontos em destaque diz respeito às estratégias de tradução dos games, principalmente, no que concerne à localização dos produtos para o mercado e público nacionais.

O estudo aqui proposto está inserido no campo disciplinar dos Estudos da Tradução (HOLMES 2004), notadamente em seu ramo descritivo orientado ao produto tradutório e tem por objetivo descrever a tradução do game Overwatch. Essa descrição busca averiguar as estratégias utilizadas pelas equipes de tradução no que tange à localização das legendas e dublagens do referido jogo para o português do Brasil e para o espanhol latino ${ }^{3}$, a partir do texto-fonte em inglês. Dessa forma, indagou-se: como se caracteriza a tradução de legendas e dublagens do jogo Overwatch? As traduções do jogo para o português do Brasil e espanhol da América apresentam traços de localização? Há distinção entre as propostas de tradução dos textos escritos, ou seja, suas legendas, e suas versões orais (dublagens)?

Para cumprir com os objetivos do estudo, lançou-se mão de recursos metodológicos elaborados especificamente para este estudo, além do suporte da Linguística de Corpus. Para tanto, compilou-se um corpus customizado de falas do jogo, cujos dados são analisados à luz de teorias relacionadas à localização.

Este estudo se justifica minimamente por dois motivos: o mercadológico e o acadêmico. Segundo o Instituto de Pesquisa de Mercado NewZoo ${ }^{4}$, o Brasil é o $11^{\circ}$ maior mercado de games do mundo em faturamento e $04^{\circ}$ em número de jogadores ${ }^{5}$. Na América Latina, o país ocupa o $1^{\circ}$ lugar.

\footnotetext{
${ }^{1}$ Disponível em: <http://g1.globo.com/tecnologia/noticia/2011/03/no-brasil-empresasinvestem-em-jogos-traduzidos-para-o-

portugues. html?keepThis=true\&TB_iframe $=$ true\&height $=600 \&$ width $=850 \&$ caption $=G 1>$. Acesso em: 11 dez. 2018

2 Neste artigo, game e jogo serão utilizados como sinônimos para se referirem especificamente aos videogames.

${ }^{3}$ Nomenclatura utilizada no jogo para referir-se ao espanhol americano.

${ }^{4}$ Mais informações em: https://newzoo.com

${ }^{5}$ Disponível em: <https://jogos.uol.com.br/ultimas-noticias/2015/07/31/estudo-indica-quebrasil-e-11-maior-mercado-de-games-no-mundo.htm>. Acesso em: $11 \mathrm{dez} .2018$
} 
Academicamente, o objetivo das pesquisas no campo disciplinar dos Estudos da Tradução "(...) é expandir a soma de (..) conhecimentos"6 (WILLIAMS; ChESTERMAN 2007: 2, tradução nossa). Segundo os autores, essa contribuição se dá de diferentes maneiras: (i) fornecendo novos dados; (ii) sugerindo respostas para indagações específicas; (iii) testando ou refinando hipóteses, teorias e metodologias já existentes; e (iv) propondo novas ideias, hipóteses, teorias e metodologias (idem). Portanto, este estudo se encaixa, especificamente, no primeiro e no segundo item, ou seja, fornece dados descritivos de processos tradutórios com base empírica e sugere perguntas e respostas para uma área, a tradução de games, cujos estudos ainda são escassos.

\section{Fundamentação teórica: localização e tradução de games}

\subsection{Localização}

Localização e globalização estão intimamente ligadas. Para Giddens, citado por Baker e Saldanha (2009: 157), a globalização intensifica as relações sociais em todo o mundo, ligando lugares distantes e moldando os acontecimentos locais.

A localização, por sua vez, poderia ser considerada o contrário da globalização. Segundo Baker e Saldanha (2009), localização pode ser definida como a adaptação linguística e cultural de conteúdo digital para os requisitos locais do mercado estrangeiro e a prestação de serviços e tecnologias para o gerenciamento do multilinguísmo por meio do fluxo digital de informação global. Dunne (2006, APUD BAKER; SALDANHA 2009: 157), define localização como o "processo pelo qual os conteúdos digitais e produtos desenvolvidos em um local (definido em termos de área geográfica, linguagem e cultura) são adaptados para venda e uso em outro lugar". (tradução nossa) ${ }^{7}$

Roscoe-Bessa, Aquino e Borges (2015: 16) afirmam que "a localização surge como uma premência diante da globalização da economia, quando ajustar um produto às demandas de um mercado local específico torna-se imprescindível". Nesse sentido, e de acordo com os autores, a tradução é uma ferramenta importante para o processo de localização, já que ela pode conferir maior eficácia à comunicação, visto que diferentes povos não compartilham os mesmos valores.

Para Munday (2009: 17), a localização abrange a adaptação de um produto às expectativas linguísticas e culturais do local alvo. Na indústria isso é visto como "um tipo especial de tradução" (idem) que leva em conta a cultura da localidade ou região onde o texto será utilizado.

\footnotetext{
${ }^{6}$ No original: “(...) increase the sum of our knowledges."

7 No original: "process by which digital content and products developed in one locale (defined in terms of geographical area, language and culture) are adapted for sale and use in another locale".
} 


\subsection{Tradução/localização de games}

A localização de games tem por objetivo, além da tradução dos códigos linguísticos, amenizar o choque cultural eventualmente causado pelo jogo em si, podendo atuar não só em textos, mas também em imagens, dublagens, cinemáticas e inclusive personagens do jogo. 0 interesse pela área no âmbito dos Estudos da Tradução vem crescendo, considerando a importante relevância do mercado de games para a economia mundial e o impacto causado no processo tradutório desse tipo de produto.

Segundo Scholand (2002), a localização de games envolve a tradução do material (não apenas textual) de um jogo para a língua alvo. 0 conteúdo pode ser todo modificado a depender do objetivo principal do cliente. A importação do maior número de referentes culturais da cultura alvo ao jogo tem por meta trazer a impressão de que o game foi desenvolvido na própria cultura receptora, causando menos estranhamento e derrubando barreiras no que se refere à jogabilidade (gameplay) ${ }^{8}$. Segundo o autor, a localização de um game pode abranger uma vasta variedade de elementos na tradução dos recursos, da documentação, compatibilidade de símbolos e configurações de teclados, compatibilidade em conversões de sistemas de medidas, compatibilidade numérica, adaptação de menus e combinações de teclas, adaptação dos processos de ordenação, adaptação da interface do usuário e adaptação de cinemáticas ${ }^{9}$ (cutscene) (SCHOLAND 2002: 5). Tudo isso sugere um trabalho com uma equipe multidisciplinar, seja em conjunto, seja separadamente. No caso deste artigo, o objeto de estudo é o material linguístico entendido como as falas do jogo (legendas e dublagens).

No entanto, segundo Pernas (2007), a diversidade de temáticas dos jogos digitais é um problema para o tradutor. Ter conhecimento interdisciplinar é imprescindível nesse aspecto; saber sobre armas, instrumentos de voo, músicas e, principalmente, conhecer a cultura fonte, são questões que determinarão o sucesso da localização em si. Para a autora, saber a função da tradução também direciona a coerência do trabalho a ser realizado. Pernas cita como exemplo os textos para o menu do game, que geralmente apresentam limite de caracteres e devem ser mais objetivos e concisos; ou textos para legenda e textos para dublagem que devem ser adequados à oralidade para que não soe pouco natural ou fora de contexto.

Méndez González (2014) reforça a ideia de que o processo de localização vai além de se trabalhar exclusivamente com o texto. Afirma que no mundo que envolve o game, tanto os textos quanto os paratextos, inclusive - trabalho de marketing e campanhas publicitárias, devem passar pelo processo de localização.

No Brasil, a localização vem ganhando importância, já que a indústria do entretenimento eletrônico vem crescendo de forma constante entre $9 \%$ e

\footnotetext{
8،“Jogabilidadeé a virtude que um jogo possui para ser fácil e intuitivo de se jogar. Quanto mais rápido o jogador se sentir confortável com os comandos do jogo e seu ambiente, mais conceituada é a 'jogabilidade'”. (VANNUCCHI; PRADO 2009: SEM PAGINAÇÃO).

${ }^{9}$ São animações utilizadas pelos games para contar a história do jogo ou dar continuidade a uma cena geralmente não jogável.
} 
$15 \%$ ao ano ${ }^{10}$. Portanto, segundo Coletti e Mota (2013), a localização de games é uma necessidade emergente e tende a crescer, posicionando os tradutores/localizadores como os formadores da nova identidade nacional no quesito de games.

No entanto, por tratar-se de um processo complexo, o ofício requer esforço, especialidade, pesquisa e uma equipe multidisciplinar para conseguir dar continuidade ao trabalho, principalmente por existirem atualizações (updates) constantes nos jogos. Esse quadro de tradutores/localizadores e demais responsáveis técnicos é importante para a divisão do trabalho e auxílio no processo e na dissolução das barreiras encontradas durante o processo de localização.

Coletti e Lennon (2013) descrevem o processo de localização e suas principais dificuldades em questões terminológicas, no quesito de referências e de direitos autorais, e as dificuldades encontradas referentes à estrutura da programação do jogo. Os autores trazem, ainda, a problemática da tradução de termos que já foram absorvidos pela comunidade gamer, mas que, em alguns casos, ainda não foram dicionarizados. Assim, a comunidade mais antiga é mais resistente a mudanças, como por exemplo, usar "atirador de elite" ou "franco atirador" no lugar de sniper pode causar estranhamento.

Para Souza (2013), uma das estratégias mais frequentemente utilizada é a da estrangeirização (VENUTI 1995), que mantém o termo na língua fonte para proferir a ideia de internacionalização do jogo; e a da domesticação (VENUTI 1995), que visa amortecer o choque cultural e localizar o jogo como se não tivesse passado pelo processo de tradução. Segundo o autor, a estrangeirização é apresentada como uma "pressão etnodesviante", com a qual se busca romper com a tradição de "fluência" e "transparência" já consagrada, em todos os campos, expondo de maneira clara a alteridade tanto linguística como cultural. Coloca a domesticação como uma "redução etnocêntrica", em que a voz do outro é de certa forma "sufocada" dentro da cultura de destino, sendo obrigada a aculturar-se a ela para garantir sua aceitação (VENUTI 1995, APUD SOUZA 2013: 54).

É importante ressaltar que os videogames passaram de "apenas entretenimento eletrônico" para um grande influenciador da cultura pop, com grande importância no cenário econômico mundial (MÉNDEZ GONZÁLEZ 2016: 753). Para o autor, de forma geral, costuma-se abordar três estratégias básicas para englobar o aspecto de possibilidades. Além da domesticação e da estrangeirização, o autor apresenta a estratégia de neutralização, que significa traduzir o termo do texto fonte (TF) sem marcas culturais (MÉNDEZ GONZÁLEZ 2016: 746).

É inegável o crescimento da presença dos games no mercado do entretenimento mundial ${ }^{11}$. Os jogos estão em todos os lugares: consoles de mesa, portáteis, celulares, redes sociais, entre outros. Os jogos são referentes culturais importantes, vide os grandes números de vendas, a presença desses produtos no dia a dia da população e a influência em outros meios, portanto, é campo fértil para a pesquisa em tradução.

10 Disponível em: <https://www.ecommercebrasil.com.br/noticias/industria-de-jogoseletronicos-um-setor-em-ascensao-no-brasil/>. Acesso em: $11 \mathrm{dez} .2018$

${ }^{11}$ Disponível em: <http://www.correiobraziliense.com.br/app/noticia/diversao-earte/2016/04/03/interna_diversao_arte,525323/os-games-invadem-a-industria-doentretenimento.shtml>. Acesso em: $11 \mathrm{dez} .2018$

TradTerm, São Paulo, v.32, dezembro/2018, p. 116-137

www.revistas.usp.br/tradterm 


\section{Metodologia}

Neste estudo, lança-se mão de instrumentos de coleta baseados na Linguística de Corpus (LC). Segundo Miroir (2016), as ferramentas computacionais da LC são utilizadas, em consonância com os Estudos Descritivos da Tradução para pesquisar o produto, ou seja, as traduções em si. Portanto, neste estudo a LC tem papel preponderante, já que possibilita a extração e o manejo de dados quantitativos, gerando valores que, por sua vez, dão subsídio para uma análise qualitativa do objeto estudado.

Para o estudo, compilou-se um corpus paralelo, customizado e unidirecional de falas de personagens (legendas e dublagens) do jogo Overwatch, contendo o TF em inglês, e suas respectivas traduções, uma para o espanhol latino ${ }^{12}$ e outra para o português do Brasil.

O corpus paralelo é a combinação de, no mínimo, dois subcorpora alinhados entre si, sendo, grosso modo, um subcorpus de textos originais na língua 1 (L1) e outro subcorpus com os textos da L1 traduzidos para uma língua 2 (L2) (FRANKENVERG-GARCíA 2008: 118). Os corpora paralelos se subdividem em: unidirecional, bidirecional ou misto. $\mathrm{Na}$ primeira configuração, a unidirecional, se permite analisar textos em uma única direção, ou seja, da L1 para a L2. Segundo Perrotti-Garcia, (2005, APUD MIROIR 2016: SEM PAGINAÇÃO), o corpus customizado é aquele que será explorado diretamente pelo tradutor (pesquisador), seja para a tradução em si, seja para pesquisa. Nesse sentido, o corpus de falas do game Overwatch, compilado com vistas a uma análise tradutológica, se encaixa nas categorias de corpus citadas anteriormente.

\subsection{O jogo (game)}

O jogo Overwatch foi concebido pela empresa Blizzard e lançado no ano de 2016. O Jogo é multiplataforma, sendo possível ser jogado em um computador que possua os requisitos mínimos de sistema, ou nos consoles de jogos Playstation 4 e Xbox One. Trata-se de um game casual, que tem como suas principais características a acessibilidade e o entretenimento, (BRANDÃo ET AL 2014: 108); além de competitivo, no modo de jogo online. 0 jogo, no momento em que foi realizada a coleta de dados, possuía 23 heróis personagens selecionáveis com habilidades distintas - e 12 mapas.

A mecânica do jogo é diferente da maioria dos games. Nele não existe um desafio linear e muito menos um grande desafio final que acarrete no seu "zeramento". 0 objetivo central não é definido e cada jogador pode escolher seu estilo pessoal de jogo. Cada partida se torna única, pois ela é jogada contra outras pessoas que também estão, em tempo real, conectadas à internet, o que foge do padrão de luta contra Inteligência Artificial proposta

\footnotetext{
${ }^{12}$ Espanhol latino é o termo utilizado pelo sistema do jogo. Embora seja um tema passível de problematização, esta não faz parte do escopo deste estudo, podendo ser abordado em outros trabalhos relacionados ao tema da tradução de games.
} 
nos jogos multiplataforma mais tradicionais. Esse propósito torna o jogo mais dinâmico e as estratégias de localização auxiliam na imersão.

\subsection{A coleta, extração e análise dos dados}

Para fins de coleta e extração dos dados, foram necessários: um televisor, um console de videogame da marca Sony modelo PlayStation $4 \mathrm{slim}$, uma mídia do jogo Overwatch (compatível com essa versão de console) e acesso à internet. Para a seleção dos idiomas, o jogo disponibiliza a opção de escolha da língua. Primeiro, selecionou-se o idioma original (inglês dos Estados Unidos), depois as versões em português do Brasil e Espanhol latino.

Uma vez selecionados os idiomas, as falas foram organizadas em quadros divididos por personagem. Os quadros contemplam, além do TF, a legenda e a fala transcrita do personagem nos idiomas português do Brasil (PTbr) e espanhol latino. Primeiramente foi alterado o idioma para inglês e a região para Estados Unidos da América para ter acesso ao conteúdo original do game, em seguida para o Espanhol latino e, por último, para o português brasileiro.

Depois desse processo, já no game, ingressou-se na área "galeria de heróis", onde ficam armazenados todos os itens selecionáveis do jogo, como roupas, poses de vitória, emotes e as falas que cada personagem utiliza durante a partida. As orações são divididas por heróis, organizados em ordem alfabética. A coleta de dados contemplou cada personagem, exceto 0 denominado como "Bastion", pois é uma representação de um robô que não apresenta falas em nenhum idioma conhecido.

As falas e as legendas foram organizadas em quadros nos idiomas inglês, espanhol latino e português brasileiro, na mesma ordem proposta no jogo. Nos quadros foram apresentadas as informações de "legenda" para o texto que representa a fala reproduzida oralmente, e a "fala" no local destinado à transcrição ${ }^{13}$ do áudio dublado no jogo nos três idiomas supracitados. Esses diálogos foram abertos, um a um, reproduzidos e transcritos. Cada personagem apresenta aproximadamente 14 falas, que são apresentadas ao jogador em uma tabela, onde se pode reproduzi-las. Dessa forma, os quadros foram construídos para discriminar a personagem, a fala escrita, a dublagem, e o idioma em que foi reproduzida a fala.

Devido às diferentes nacionalidades dos personagens, frequentemente não foi possível coletar o áudio e sua transcrição, já que alguns deles utilizam a fala em seu idioma original, como russo, japonês e egípcio. Nesse caso, as falas foram catalogadas nos quadros como "ininteligível". Com isso, foram gerados 66 quadros no total, formando o corpus multilíngue de falas e legendas do jogo.

O corpus, por sua vez, foi subdivido em subcorpora por idioma e por personagem sendo: subcorpus de falas (transcrições) e subcorpus de legendas nos três idiomas. Essa subdivisão se dá devido à necessidade de comparação

\footnotetext{
${ }^{13}$ Por não fazer parte do escopo deste trabalho, não foi realizada uma transcrição ortográfica conforme modelos de transcrição já estabelecidos. Para mais informação sobre transcrição ortográfica, sugere-se: RAMILO E FREITAS: 2001.
} 
inter e intracorpora. O Quadro 1, a seguir, representa a organização do corpus e seus subcorpora.

Quadro 1- Leiaute dos quadros com as falas (legenda e transcrição) dos personagens nos três idiomas

\begin{tabular}{l|c|c|c|c|c}
\hline \multicolumn{3}{c}{ Personagem } \\
\hline \multicolumn{2}{c|}{ Inglês } & \multicolumn{2}{c}{ Espanhol } & \multicolumn{2}{c}{ Português } \\
\hline Legenda & Transcrição & Legenda & Transcrição & Legenda & Transcrição \\
\hline
\end{tabular}

Uma vez extraídas as falas, os textos foram convertidos para a extensão txt. Depois de convertidos, foi utilizado o programa AntConc ${ }^{14}$, versão $3.4 .4 \mathrm{~W}$ para a extração de dados como: 1. Número de formas (types); 2 . Número de itens (tokens) e 3. Razão types/tokens, que, segundo Berber Sardinha, na prática "indica a riqueza lexical do texto. Quanto maior seu valor, mais palavras diferentes o texto conterá". (BERBER SARDINHA 2004: 94).

Foram geradas, ainda, listas de palavras (Word list), com as quais é possível averiguar quais são os itens mais frequentes no corpus e em cada subcorpus. Este recurso foi utilizado concomitante a aplicação de uma stop list, cuja função principal é a retirada de itens da lista de palavras. No caso deste estudo, foram retirados todos os itens sem carga semântica. Esse procedimento é necessário para que itens gramaticais não interfiram no cálculo da razão que indica a riqueza lexical de cada subcorpus.

\subsubsection{Das análises quantitativa e qualitativa}

A análise quantitativa dos dados visou à comparação entre os subcorpora bem como sua descrição. Nessa análise, os números totais e relativos representam a estrutura dos corpora no que tange à quantidade de palavras (itens), sua riqueza lexical (razão types/tokens), palavras mais frequentes e mais repetidas no corpus. Esses dados funcionam como descritores do corpus.

A análise qualitativa visou ao cotejo dos dados coletados desde a perspectiva dos Estudos da Tradução, ou seja, identificando traços de localização no material linguístico que compõe o corpus. A análise possui natureza comparativa, posto que o corpus é formado por, minimamente, três subcorpora, analisados de forma individual (intercorpus) e de forma conjunta (intracorpora). 0 corpus customizado de falas e legendas do jogo é composto por 6 subcorpora: Corpus de legendas e de dublagens em Inglês (COLING e CODING respectivamente); corpus de legendas e de dublagens em espanhol (COLESP e CODESP respectivamente); corpus de legendas e dublagens em português (COLPOR e CODPOR respectivamente).

\section{Apresentação e discussão dos dados}

\footnotetext{
${ }^{14}$ Disponível em: <http://www.laurenceanthony.net/software/antconc/>. Acesso em: $12 \mathrm{dez}$. 2018.
} 


\subsection{Dados quantitativos (descrição)}

As falas somam um total de 310 sentenças selecionáveis e utilizáveis pelo jogador no decorrer do jogo, e, no total, 1860 falas, entre transcrição de áudio e legenda. 0 Gráfico 1 representa o corpus com o número total de falas e número de falas localizadas e não localizadas nos três idiomas.

Gráfico 1-Total de falas por idiomas

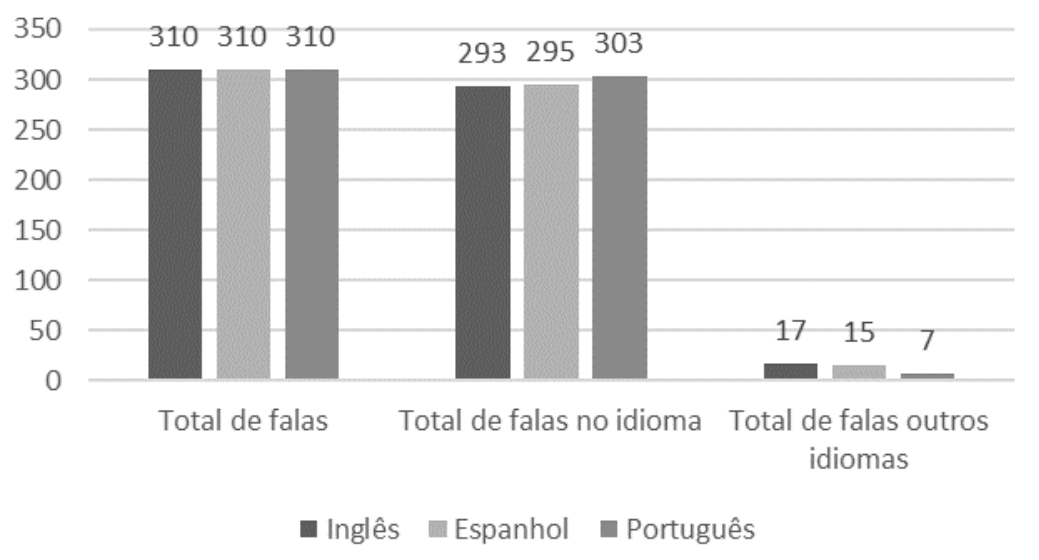

Fonte: elaboração própria

No texto em inglês, nota-se que 17 falas foram mantidas no idioma original de personagens que não têm origem anglo-saxônica. No caso do espanhol, todas as falas mantidas inicialmente na versão do jogo em inglês também foram mantidas na versão em espanhol, à exceção de 2 falas para o texto original da personagem Sombra, que, por ter origem mexicana, já apresenta algumas falas em espanhol.

Em português, nota-se que o game sofreu mais localização que a versão em espanhol. Apenas 7 falas, das 310 sentenças a serem traduzidas, foram mantidas em outra língua, obedecendo, assim, o "padrão" do texto original. Nesse sentido, a versão brasileira localiza mais que a versão em espanhol.

A opção da equipe brasileira pela localização do jogo, adaptando o texto original para conferir a ideia de origem nacional ao game, pode ser notada pelos termos mais localizados e utilização de gírias ${ }^{15}$ e memes $^{16}$. A tradução do game para o idioma espanhol, por sua vez, tenta ser mais "fiel"17 ao TF, utilizando-se de ferramentas localizadoras apenas em situações extremas. 0 Gráfico 2 traz esses dados:

\footnotetext{
${ }^{15}$ Neste trabalho, usamos a seguinte definição de gíria: "A Linguagem, em geral efêmera, marcada por vocabulário novo, ou já existente, porém com outra significação, e construções metafóricas, muitas vezes cômicas. A gíria se popularizou e é usada hoje por diferentes grupos sociais" (Fonte: Dicionário Michaelis).

${ }^{16}$ Trata-se de uma imagem, vídeo ou frase bem-humorada que se espalha na internet como um vírus. (SOUSA; GOBBI 2014: 129-145).

17 “Pensar a tradução como fidelidade é pensar em equivalência entre as línguas de partida e de chegada, onde haveria sempre uma unidade equivalente na língua de chegada para a escolhida na língua de partida" (PENA 2009: 1)
}

TradTerm, São Paulo, v.32, dezembro/2018, p. 116-137

www.revistas.usp.br/tradterm 
Gráfico 2 - Sentenças em outros idiomas, localizadas e não localizadas

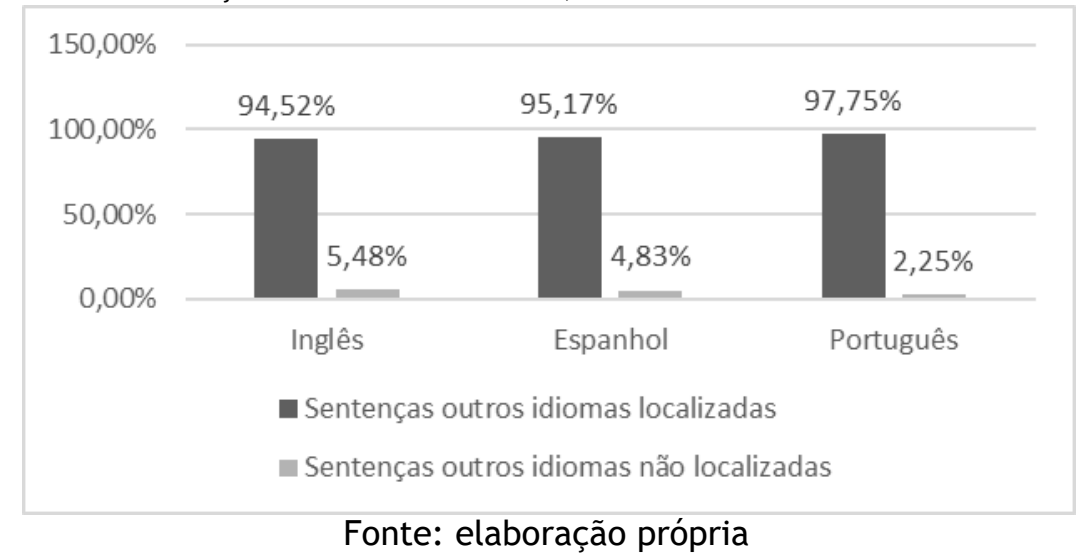

Conforme citado na Metodologia, alguns personagens mantêm seus idiomas de origem (japonês, mandarim etc.), e alguns deles não são traduzidos em nenhuma das versões, nem no jogo original em inglês. Ao comparar os dados (Gráfico 2), observa-se que a versão brasileira é a que mais localizou essas sentenças, ou seja, $97,75 \%$ delas foram localizadas, enquanto em espanhol e inglês o número cai ( $94,52 \%$ no inglês e $95,17 \%$ no espanhol). 0 Gráfico 3 a seguir representa a estrutura do corpus.

Gráfico 3- Número de tokens e types de cada subcorpus de legenda e dublagem

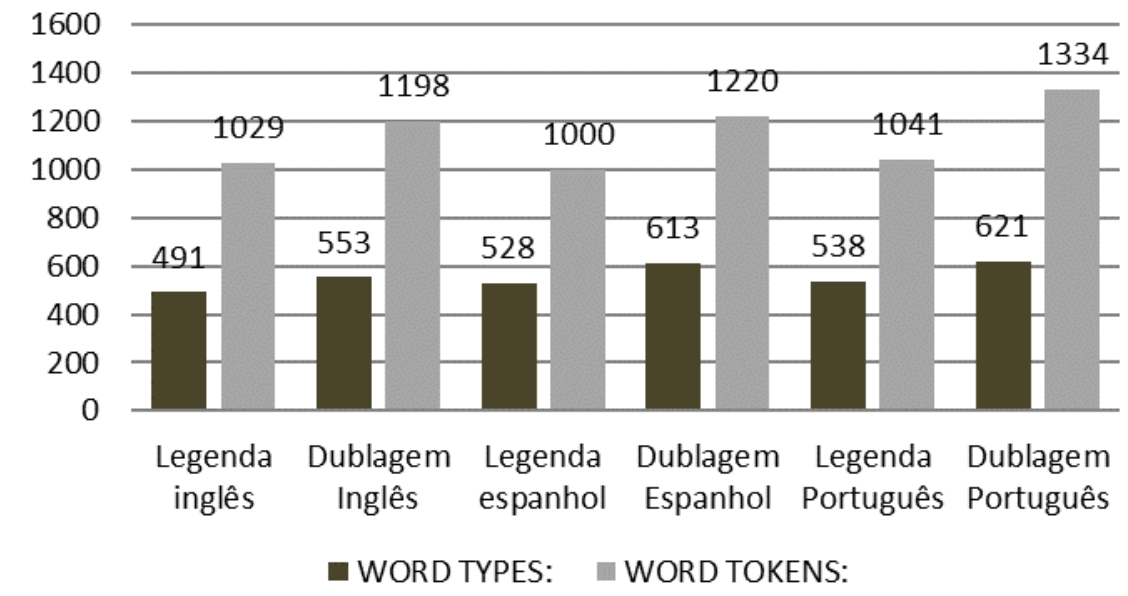

Fonte: elaboração própria

Conforme Gráfico 3, o corpus de legendas e dublagem em inglês (2227 tokens) se assemelha muito ao corpus em espanhol, com 2220 tokens. Se por um lado os dois corpora, inglês e espanhol, se assemelham, por outro, o corpus do português apresenta um número superior de tokens, 2375, ou seja, 148 tokens a mais que o corpus em inglês e 155 a mais que o corpus em espanhol. Essa diferença pode significar maior riqueza léxica no caso do português comparado com os outros dois corpora. Vale observar que a maior diferença é observada no CODPOR, cujo número de tokens e types é maior que nos outros subcorpora. Com o fito de se buscar comprovar esse resultado, calculou-se a razão entre tokens e types. Os resultados estão disponíveis na Tabela 1, a seguir.

Tabela 1-Número de tokens, types e razão tokens/types

TradTerm, São Paulo, v.32, dezembro/2018, p. 116-137

www.revistas.usp.br/tradterm 


\begin{tabular}{lcccccc}
\hline & $\begin{array}{c}\text { Legenda } \\
\text { Inglês }\end{array}$ & $\begin{array}{c}\text { Dublagem } \\
\text { Inglês }\end{array}$ & $\begin{array}{c}\text { Legenda } \\
\text { Espanhol }\end{array}$ & $\begin{array}{c}\text { Dublagem } \\
\text { Espanhol }\end{array}$ & $\begin{array}{c}\text { Legenda } \\
\text { Português }\end{array}$ & $\begin{array}{c}\text { Dublagem } \\
\text { Português }\end{array}$ \\
\hline WORD TYPES & 491 & 553 & 528 & 613 & 538 & 621 \\
WORD TOKENS & 1029 & 1198 & 1000 & 1220 & 1041 & 1334 \\
TOKENS/TYPES & 2,10 & 2,17 & 1,89 & 1,99 & 1,93 & 2,15 \\
\hline
\end{tabular}

Fonte: elaboração própria

Acordes com Berber Sardinha (2004), quanto maior a diferença na razão entre tokens e types, maior a riqueza lexical do corpus em questão. Portanto, se analisados separadamente, o CODING é o subcorpus com maior riqueza lexical, com razão de 2,17, seguido do CODPOR, com razão de 2,15 (Tabela 1). Contudo, esses dados levam em consideração todas as formas (tokens), ou seja, o total de itens (types) ou palavras considerando as repetições, o que significa que palavras sem carga semântica são consideradas. Levando em conta que essas palavras geralmente são as mais frequentes em um corpus, o dado aqui apresentado pode estar enviesado.

Para minimizar esse problema, por meio da ferramenta stop list, todas as palavras gramaticais foram retiradas da contagem, gerando uma nova Word list com novos dados numéricos, conforme mostrado na Tabela 2.

Tabela 2- Número de tokens, types e razão tokens/types aplicando a stop list.

\begin{tabular}{lcccccc}
\hline & $\begin{array}{l}\text { Legenda } \\
\text { inglês }\end{array}$ & $\begin{array}{l}\text { Dublagem } \\
\text { Inglês }\end{array}$ & $\begin{array}{l}\text { Legenda } \\
\text { espanhol }\end{array}$ & $\begin{array}{c}\text { Dublagem } \\
\text { Espanhol }\end{array}$ & $\begin{array}{l}\text { Legenda } \\
\text { Português }\end{array}$ & $\begin{array}{c}\text { Dublagem } \\
\text { Português }\end{array}$ \\
\hline WORD TYPES & 553 & 448 & 543 & 451 & 588 & 508 \\
WORD TOKENS & 1198 & 1023 & 544 & 589 & 1108 & 874 \\
TOKENS/TYPES & 2,17 & 2,28 & 1,00 & 1,31 & 1,88 & 1,72 \\
\hline
\end{tabular}

Fonte: elaboração própria

Aplicada a stop list, os resultados confirmam maior riqueza lexical nos dois subcorpora do inglês, com razão tokens/types de 2,17 e 2,28 no COLING e CODING respectivamente; e 1,88 e 1,72 no COLPOR e no CODPOR, respectivamente. O corpus em espanhol é, portanto, o menos rico lexicalmente, com 1,0 e 1,31 no COLESP e CODESP, respectivamente.

A mesma configuração se repete quando os corpora de legenda e dublagem são unificados. O corpus em inglês continua sendo o mais rico, com 2221 tokens, 1001 types e razão de 2,21. O corpus em português vem em segundo lugar, com 1982 tokens, 1096 types e razão de 1,80. Por último, novamente está o corpus em espanhol, com 1133 tokens, 994 types e razão de 1,13 .

Por modalidade de tradução, os corpora são representados conforme Gráfico 4. 
Gráfico 4 - Comparativo intercorpora por modalidade de tradução sem stop list.

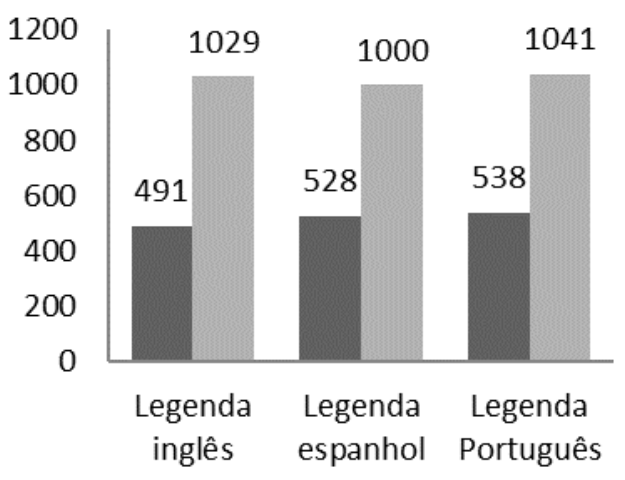

- WORD TYPES $\square$ WORD TOKENS



- WORD TYPES $\square$ WORD TOKENS

Sem aplicar a stop list, observa-se que tanto na legenda quanto na dublagem, o corpus do português é o maior, também considerando tokens e types. Ao observar os dados da modalidade dublagem, nota-se que o CODESP é maior que o CODING, contrariando os dados anteriores em que o corpus em espanhol era sempre menor. Isso pode ser explicado devido à modalidade e à estrutura dos sistemas linguísticos em si. Enquanto o CODING utiliza menos palavras e menos repetições, o CODESP e o CODPOR utilizam mais palavras com mais repetições.

Isso pode ocorrer devido ao fato de tanto o português quanto o espanhol possuírem mais categorias de itens lexicais sem carga semântica que o inglês. Se tomamos, a título de exemplo, o uso de artigo definido, somente nesta classe de palavras se observará uma diferença de 4 vezes, nas duas línguas latinas comparadas à anglo-saxônica. Enquanto o inglês utiliza o artigo the tanto para expressar gênero como número, o espanhol e o português utilizam quatro formas distintas, el, la, los, las e o, a, os, as, respectivamente. Isso por si gera uma diferença no número de tokens (total de palavras) e no número de types (total de palavras sem repetição). Por isso, a necessidade de retirada deste tipo de palavra do corpus para uma análise mais fidedigna dos dados referentes à riqueza lexical. Os dados após a aplicação da stop list estão representados no Gráfico 5.

Gráfico 5 - Comparativo intercorpora por modalidade de tradução com stop list.
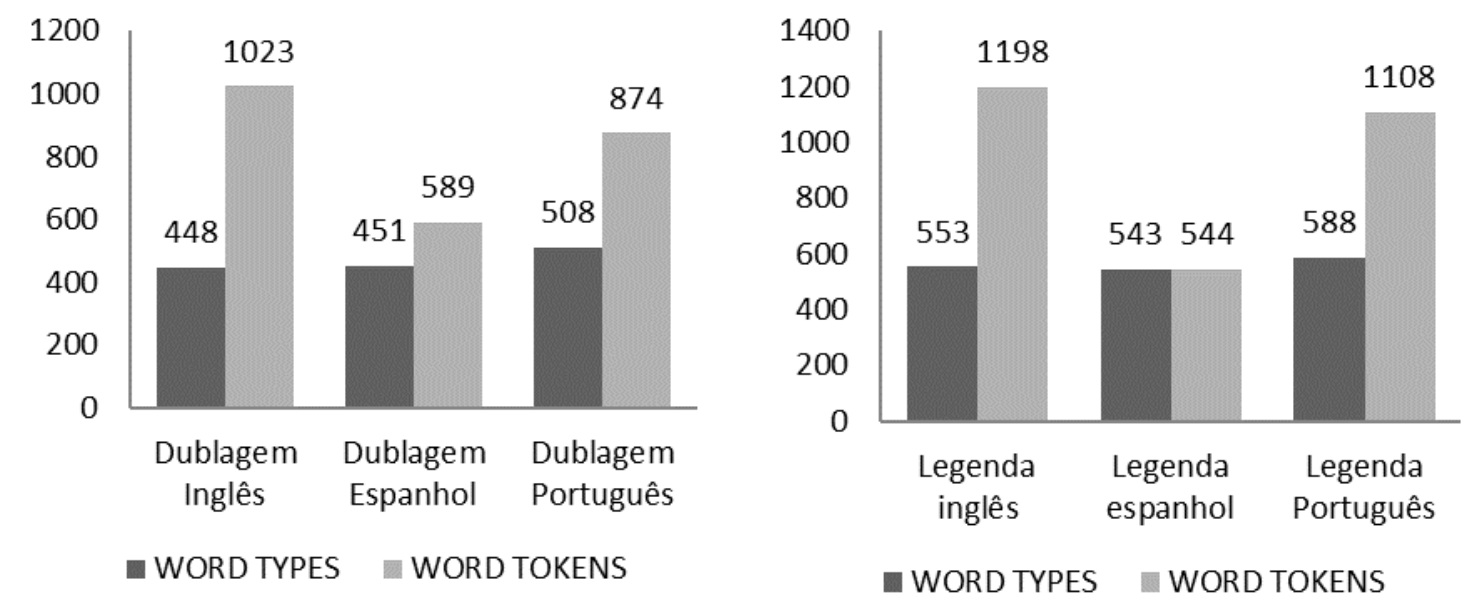

Os dados expostos no Gráfico 5 comprovam a hipótese aventada anteriormente, ou seja, que as diferenças dos sistemas linguísticos impactam 
os dados. Observe-se que, diferentemente do que ocorreu com os dados antes da aplicação da stop list, o corpus em português era o maior. Com a aplicação da stop list, o corpus do inglês passa a ser o maior, tanto na modalidade dublagem como na modalidade legenda. Ao calcular a razão entre tokens e types, comprova-se a maior riqueza lexical no inglês em todos os subcorpora $($ CODING $=2,28 ;$ COLING $=2,16 ;$ CODPOR= 1,72; COLPOR= 1,88; CODESP= 1,30; COLESP=1,0). Um dado que merece destaque diz respeito à legenda em espanhol, na qual tokens e types possuem praticamente o mesmo valor, o que denota que as palavras repetidas nesta modalidade são mínimas.

Numa perspectiva intracorpus e desconsiderando a stop list, os corpora encontram-se assim representados:

Gráfico 6 - Comparação intracorpora entre modalidades de tradução sem stop list.

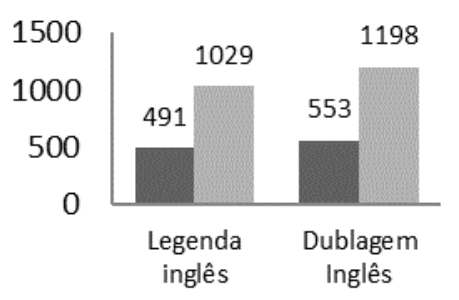

- WORD TYPES $\quad$ WORD TOKENS

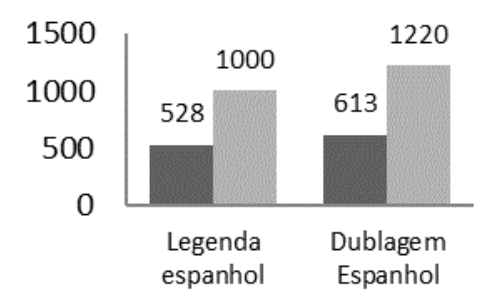

- WORD TYPES $\quad$ WORD TOKENS



-WORD TYPES $\quad$ WORD TOKENS

Observa-se no Gráfico 6 que, dentro de mesmo idioma, a dublagem sempre possui maior número de tokens e types. Isso se dá devido às características de cada modalidade, tendo a dublagem mais liberdade no que se refere à quantidade de palavras utilizadas. Ao aplicar a stop list, os dados sofrem alterações significativas, conforme mostra o Gráfico 7.

Gráfico 7 - Comparação intracorpora entre modalidades de tradução com stop list.

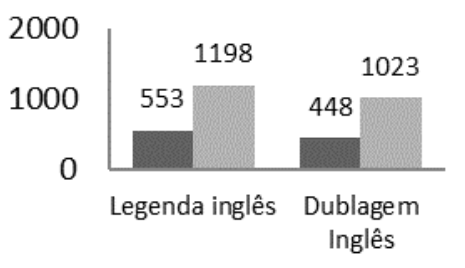

WORD TYPES $\quad$ WORD TOKENS

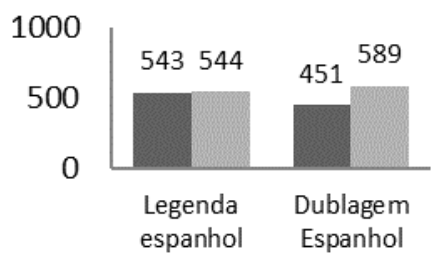

WORD TYPES $\quad$ WORD TOKENS



- WORD TYPES $\quad$ WORD TOKENS

Ao contrário do que ocorreu na análise sem a aplicação da stop list, quando os dados revelam que na modalidade dublagem todos os corpora eram maiores comparados com a modalidade legenda; ao aplicar a stop list, observa-se que em inglês e português a modalidade legenda apresenta maior número de tokens e types que a modalidade Dublagem. Isso indica que, nesses dois sistemas linguísticos, há um número grande de palavras gramaticais (sem carga semântica) em uso. No caso da língua espanhola, também se registra maior número de tokens na dublagem, mas ao contrário do inglês e do português, o número de types da dublagem foi inferior ao número de types da legenda, o que pode significar que o texto da dublagem em espanhol é mais simples que o da legenda.

\subsection{Dados qualitativos}


Os dados quantitativos mostraram como as falas estão distribuídas em cada um dos corpora nos três idiomas. Nessa análise, viu-se que a versão em português das falas é a que mais apresenta características de localização. A seguir, serão analisados qualitativamente alguns casos emblemáticos.

Outro dado quantitativo importante é o que demonstrou que, em algumas situações, as traduções mantêm estruturas parecidas, tanto na modalidade como no idioma, com o texto original (Quadro 2). Porém, em diversos outros casos, os textos foram alterados completamente, dando outro sentido e passando uma mensagem distinta do TF.

Quadro 2 - Exemplo de fala da personagem D.VA nos três idiomas, localizadas no português Personagem: D.VA

\begin{tabular}{c|c|c|c|c|c}
\hline \multicolumn{2}{c|}{ Inglês } & \multicolumn{2}{c}{ Espanhol } & \multicolumn{2}{c}{ Português } \\
\hline Legenda & Dublagem & Legenda & Dublagem & Legenda & Dublagem \\
\hline I play to win & $\begin{array}{c}\text { Ininteligível } \\
\text { (Coreano) }\end{array}$ & $\begin{array}{c}\text { Juego para } \\
\text { ganar }\end{array}$ & $\begin{array}{c}\text { Ininteligível } \\
\text { (Coreano) }\end{array}$ & $\begin{array}{c}\text { Eu jogo pra } \\
\text { ganhar }\end{array}$ & $\begin{array}{c}\text { Eu jogo pra } \\
\text { vencer }\end{array}$ \\
\hline
\end{tabular}

Conforme o Quadro 2 - Exemplo de fala da personagem D.VA2, nota-se que, no TF em inglês na modalidade dublagem, a personagem utiliza-se de seu idioma materno (coreano), o que é mantido na versão do game em espanhol. Porém, quando se analisa o trecho em português do Brasil, o mesmo trecho foi traduzido tanto na legenda quando na dublagem, abrindo mão do estrangeirismo.

Em outros momentos essa situação também se repetiu, como no exemplo referente ao personagem Genji. A influência utilizada pela equipe de localização Brasileira pode ser identificada nas seis falas elencadas a seguir:

Quadro 3 - Exemplos de falas do personagem Genji nos três idiomas, localizadas no português Personagem: Genji

\begin{tabular}{c|c|c|c|c|c}
\hline \multicolumn{2}{c|}{ Inglês } & \multicolumn{2}{c|}{ Espanhol } & \multicolumn{2}{c}{ Português } \\
\hline Legenda & Dublagem & Legenda & Dublagem & Legenda & Dublagem \\
\hline Let's Fight! & $\begin{array}{c}\text { Ininteligível } \\
\text { (Japonês) }\end{array}$ & iLuchemos! & $\begin{array}{c}\text { Ininteligível } \\
\text { (Japonês) }\end{array}$ & Vamos à luta & $\begin{array}{c}\text { Vamos, } \\
\text { lutemos com } \\
\text { honra }\end{array}$ \\
\hline $\begin{array}{c}\text { My soul seeks } \\
\text { balance }\end{array}$ & $\begin{array}{c}\text { Ininteligível } \\
\text { (Japonês) }\end{array}$ & $\begin{array}{c}\text { Mi alma } \\
\text { busca } \\
\text { equilíbrio }\end{array}$ & $\begin{array}{c}\text { Ininteligível } \\
\text { (Japonês) }\end{array}$ & $\begin{array}{c}\text { Minha alma } \\
\text { busca o } \\
\text { equilíbrio }\end{array}$ & $\begin{array}{c}\text { Minha alma } \\
\text { busca o } \\
\text { equilíbrio }\end{array}$ \\
\hline $\begin{array}{c}\text { Damn! } \\
\text { I am }\end{array}$ & $\begin{array}{c}\text { Ininteligível } \\
\text { (Japonês) }\end{array}$ & $\begin{array}{c}\text { Maldición } \\
\text { prepared! } \\
\text { (Japonếsel }\end{array}$ & $\begin{array}{c}\text { Ininteligível } \\
\text { (Japonês) }\end{array}$ & Droga! & Merda! \\
\hline Yeah! & $\begin{array}{c}\text { Ininteligível } \\
\text { (Japonês) }\end{array}$ & $\begin{array}{c}\text { Ininteligível } \\
\text { (Japonês) }\end{array}$ & $\begin{array}{c}\text { Estou } \\
\text { preparadoligível } \\
\text { (Japonês) }\end{array}$ & $\begin{array}{c}\text { Estou } \\
\text { preparado! }\end{array}$ \\
\hline $\begin{array}{c}\text { Not good } \\
\text { enough! }\end{array}$ & $\begin{array}{c}\text { Ininteligível } \\
\text { (Japonês) }\end{array}$ & $\begin{array}{c}\text { Pero no es } \\
\text { suficiente }\end{array}$ & $\begin{array}{c}\text { Ininteligível } \\
\text { (Japonês) }\end{array}$ & $\begin{array}{c}\text { Não é forte o } \\
\text { suficiente }\end{array}$ & Ainda não \\
\hline
\end{tabular}

Tanto na versão em inglês como na versão em espanhol, o idioma japonês é utilizado na dublagem. Já na versão brasileira, esses trechos são 
traduzidos e localizados para o português. No caso da localização para o espanhol, o uso da estrangeirização, e acordes com Souza (2013), é uma ação que passa a ideia de internacionalização do texto, e ainda segue a linha mais literal ao texto original. No caso da versão brasileira, completamente traduzida à língua meta, dá-se ao texto (produto) uma natureza local, ou seja, como se ele fosse um produto nacional para o jogador, cuja probabilidade de se identificar com o personagem talvez seja maior.

Em outras situações, nota-se que a localização do game em português do Brasil apresenta uma liberdade de escolha não vista em espanhol. Foram encontrados casos em que as referências culturais são inseridas visando uma identificação com um nicho específico da cultura pop atual, relacionado ao mundo geek, nerd e da internet ${ }^{18}$. Outros elementos intrínsecos a essa comunidade são utilizados com referências diretas para o "alívio cômico" ${ }^{19}$ do game - que é a inclusão, neste caso, de uma sentença para quebrar o ritmo de seriedade enraizado durante o texto, além de se aproximar mais do público de maneira indireta.

O personagem que mais apresenta essa caraterística localizadora é Lúcio, um DJ negro, da periferia do Rio de Janeiro. Talvez por ser um personagem que represente a cultura nacional, os localizadores optaram por adotar diversas falas que fossem intrínsecas à cultura brasileira, permitindo, assim, criar novas ideias, propostas e personalidade para o personagem que representa a própria cultura de chegada, conforme ilustrados no Quadro 4.

Quadro 4 - Exemplos de falas do personagem brasileiro Lúcio

Personagem: Lúcio

\begin{tabular}{c|c|c|c|c|c}
\hline \multicolumn{2}{c|}{ Inglês } & \multicolumn{2}{c|}{ Espanhol } & \multicolumn{2}{c}{ Português } \\
\hline Legenda & Dublagem & Legenda & Dublagem & Legenda & Dublagem \\
\hline $\begin{array}{c}\text { Can't stop, } \\
\text { won't stop }\end{array}$ & $\begin{array}{c}\text { Can't stop, } \\
\text { won't stop }\end{array}$ & $\begin{array}{c}\text { No puedo } \\
\text { parar, ni } \\
\text { quiero }\end{array}$ & $\begin{array}{c}\text { No puedo } \\
\text { parar, ni } \\
\text { quiero }\end{array}$ & $\begin{array}{c}\text { Não para, } \\
\text { não para, } \\
\text { não para } \\
\text { não }\end{array}$ & $\begin{array}{c}\text { Não para, } \\
\text { não para, } \\
\text { não para } \\
\text { não }\end{array}$ \\
\hline $\begin{array}{c}\text { Why are } \\
\text { you so } \\
\text { angry? }\end{array}$ & $\begin{array}{c}\text { Why are you } \\
\text { so angry? }\end{array}$ & $\begin{array}{c}\text { ¿Por qué } \\
\text { tan } \\
\text { molesto? }\end{array}$ & $\begin{array}{c}\text { ¿Ahh, por } \\
\text { qué tan } \\
\text { molesto? }\end{array}$ & $\begin{array}{c}\text { Pra que } \\
\text { tanto ódio } \\
\text { no coração, } \\
\text { parça? }\end{array}$ & $\begin{array}{c}\text { Pra que } \\
\text { tanto ódio } \\
\text { no coração, } \\
\text { parça? }\end{array}$ \\
\hline
\end{tabular}

No Quadro 4, em inglês e espanhol, nota-se que a fala do personagem não remete a nada específico. Contudo, em inglês, a fala mantém uma melodia, como se estivesse cantando um refrão. Em espanhol ele apenas

\footnotetext{
${ }^{18}$ Segundo Galvão, 2009, p. 35-36 (apud MATos 2011: 3) "Devido a essa nova sociedade que exige, cada vez mais, conhecimento em tecnologias, predisposição a novidades, dedicação aos estudos, curiosidade científica etc." o nerd teria se tornado "aquela pessoa que todos consultam". E o termo "geek" aparece como um sinônimo de nerd, mas sem a conotação pejorativa, e também como uma espécie de subgrupo (MATOS 2011: 4).

19 "an amusing scene, incident, or speech introduced into serious or tragicelements, as in a pl ay, in order to provide temporary relief fromtension, or to intensify the dramatic action.

Relief from tension caused by the introduction or occurrence of a comicelement, as by an am using human foible"

Cf. Dictionary.com. Disponível em: http://www.dictionary.com/browse/comic-relief. Acesso em 13 jun. 2017
} 
reproduz a fala, anulando esse traço característico. No caso da tradução e da dublagem brasileiras, o personagem fala, cantarolando, a sentença "Não para, não para, não para não", que é uma letra popular de um funk carioca, inserindo uma propriedade cultural e fazendo uma referência à origem e profissão do personagem de forma direta.

Para Méndez González (2016: 746), a domesticação não tem limites, desde que se tenha bom senso e principalmente se respeite o objetivo do game como base para o trabalho, seja retirando as marcas culturais da cultura fonte seja trazendo elementos da cultura alvo para o texto. Esse tipo de localização introduziu um referente cultural marcante o suficiente para ser reconhecido por grande parte do público alvo.

Ainda se tratando do personagem Lúcio (Quadro 4), constata-se que a tradução utilizada não seguiu nenhum padrão específico. Porém, ao inserir uma gíria difundida no âmbito econômico-social das favelas do Rio de Janeiro -parça-, a estratégia de domesticação cumpre com sua função não só na identificação do jogador brasileiro com o personagem, como também com sua caracterização.

A gíria em português não existe no texto original, tampouco é possível notar traços de sotaque que o falante brasileiro possui quando fala inglês. Igualmente, a versão espanhola do game não foi localizada. A gíria é utilizada, em sua grande maioria, por jovens, salvo em casos de jargões - ou termos - profissionais usados por classes de trabalhadores específicas, ou de nichos sociais característicos.

Nessa situação, a palavra "parça" traz uma brasilidade à fala, e, também, dá um sentido mais apaziguador, como se o personagem fosse uma pessoa tranquila, da paz. Esse tipo de entendimento só é possível graças ao acréscimo dessa palavra na versão brasileira, com a qual, em conjunto com o complemento da frase utilizada na fala de Lúcio (Quadro 4) forma-se um meme. Essa "fuga" da tradução literal pode ser averiguada nos seguintes exemplos, retirados da mesma personagem.

Quadro 5 - Exemplos de falas localizadas para o personagem brasileiro Lúcio Personagem: Lúcio

\begin{tabular}{|c|c|c|c|c|c|}
\hline \multicolumn{2}{|c|}{ Inglês } & \multicolumn{2}{|c|}{ Espanhol } & \multicolumn{2}{|c|}{ Português } \\
\hline Legenda & Dublagem & Legenda & Dublagem & Legenda & Dublagem \\
\hline $\begin{array}{l}\text { I'm on top } \\
\text { of the } \\
\text { world }\end{array}$ & $\begin{array}{l}\text { I'm on top } \\
\text { of the } \\
\text { world }\end{array}$ & $\begin{array}{c}\text { Estoy en la } \\
\text { cima del } \\
\text { mundo }\end{array}$ & $\begin{array}{c}\text { Estoy en la } \\
\text { cima del } \\
\text { mundo }\end{array}$ & $\begin{array}{l}\text { Eu sou } \\
\text { sinistro }\end{array}$ & $\begin{array}{l}\text { Eu sou } \\
\text { sinistro }\end{array}$ \\
\hline Killed it! & Killed it! & $\begin{array}{l}\text { ¡Hasta } \\
\text { nunca! }\end{array}$ & La rompí & Arrebentei. & Arrebentei. \\
\hline Oh, Yeah! & Oh, Yeah! & ¡Oh, sí! & ¡Oh, sí! & Ah, Garoto! & Ah, Garoto! \\
\hline
\end{tabular}

Novamente, no Quadro 5 se observa que, no caso do espanhol, a tradução é bastante "fiel" à estrutura da LF, traduzida palavra por palavra e com o mínimo de variações possíveis. Por sua vez, na tradução à língua portuguesa, os localizadores utilizaram-se de gírias para aproximar o personagem da cultura nacional. Esse tipo de estratégia faz com que 0 jogador sinta que o game foi feito em sua própria terra. 
Outro ponto que parece ter influenciado a localização, principalmente do personagem Lúcio, é o fato de ele fazer parte do contexto da cultura de chegada, ou seja, a equipe de localização do game, por também fazer parte dessa mesma cultura, talvez tenha se sentido mais à vontade para "brincar" com esse personagem, devido ao conhecimento mais apurado da cultura de chegada. Aventa-se que, no caso da língua espanhola, essa relação não exista, já que para os jogadores hispanos o personagem é estrangeiro, enquanto para os brasileiros, não.

Referências à cultura pop, atualmente muito difundida entre jovens e em grande parte do público alvo do game, é outra característica muito presente. Essas referências foram encontradas no TF e em algumas localizações, principalmente na dublagem do jogo para o português do Brasil. Os seguintes exemplos ilustram a afirmativa.

Quadro 6 - Exemplos de falas do personagem Mccree nos três idiomas e localizado no português

Personagem: McCree

\begin{tabular}{c|c|c|c|c|c}
\hline \multicolumn{2}{c|}{ Inglês } & \multicolumn{2}{c|}{ Espanhol } & \multicolumn{2}{c}{ Português } \\
\hline Legenda & Dublagem & Legenda & Dublagem & Legenda & Dublagem \\
\hline $\begin{array}{c}\text { Happens to } \\
\text { the best of } \\
\text { us }\end{array}$ & $\begin{array}{c}\text { Happens to } \\
\text { the best of } \\
\text { us }\end{array}$ & $\begin{array}{c}\text { Le pasa } \\
\text { hasta a los } \\
\text { mejores }\end{array}$ & $\begin{array}{c}\text { Le pasa } \\
\text { hasta a los } \\
\text { mejores }\end{array}$ & $\begin{array}{c}\text { Acontece } \\
\text { nas } \\
\text { melhores } \\
\text { famílias }\end{array}$ & $\begin{array}{c}\text { Acontece } \\
\text { nas } \\
\text { melhores } \\
\text { famílias }\end{array}$ \\
\hline $\begin{array}{c}\text { I'm your } \\
\text { huckleberry }\end{array}$ & $\begin{array}{c}\text { I'm your } \\
\text { huckleberry }\end{array}$ & $\begin{array}{c}\text { Soy quien } \\
\text { buscas }\end{array}$ & $\begin{array}{c}\text { Soy quien } \\
\text { buscas }\end{array}$ & $\begin{array}{c}\text { Eu sou o } \\
\text { cara }\end{array}$ & $\begin{array}{c}\text { Eu sou o } \\
\text { cara }\end{array}$ \\
\hline $\begin{array}{c}\text { I'm the } \\
\text { quick... }\end{array}$ & $\begin{array}{c}\text { I'm the } \\
\text { quick, } \\
\text { you're the } \\
\text { dead. }\end{array}$ & Soy rápido... & $\begin{array}{c}\text { Soy rápido, } \\
\text { y mortal }\end{array}$ & $\begin{array}{c}\text { Eu sou o } \\
\text { rápido... }\end{array}$ & $\begin{array}{c}\text { Eu vou te... } \\
\text { abati. }\end{array}$ \\
\hline
\end{tabular}

No primeiro exemplo do Quadro 6, uma tradução literal, em português, para a sentença "Happens to the best of us" seria "Acontece com os melhores de nós", procedimento que parece ter sido utilizado na tradução para o espanhol. Porém, em português, é utilizada uma expressão cultural marcante: "Acontece nas melhores famílias". Essa expressão acrescenta signos não encontrados no TF e, tampouco, na tradução ao espanhol. Em português foi utilizada a expressão como forma de domesticação para aproximar e dar o sentido de "nacionalidade" ao game.

No segundo exemplo, ainda no Quadro 6, a expressão cultural é apresentada em inglês, I'm your huckleberry, gerando um problema para sua localização. Em espanhol a saída utilizada foi transcrever o significado da expressão, utilizando “Soy quien buscas". Em português, a equipe utilizou-se de uma referência a outra expressão comumente utilizada pelos jovens em forma de gíria para domesticá-la: "Eu sou o cara". O mesmo ocorre com o terceiro exemplo (Quadro 6) cuja sentença em inglês, "l'm the quick...", é traduzida de forma literal em espanhol por: "Soy rápido..." e em português é domesticada utilizando a expressão: "Eu vou te... abati", conferindo idiomatismo ao texto alvo. 
Algumas referências da cultura popular são utilizadas para dar ao game uma imagem de contemporaneidade e direcioná-lo a um público específico de jovens e admiradores da cultura pop. Isso pode ser observado na fala da personagem Mei, que utiliza uma arma de gelo. A referência direta ao filme Frozen, da Disney ${ }^{20}$ pode ser observada no exemplo demonstrado do Quadro 7.

Quadro 7 - Exemplos de fala da personagem Mei nos três idiomas e localizado no português do Brasil

\begin{tabular}{c|c|c|c|c|c}
\hline \multicolumn{2}{c}{ Personagem: Mei } \\
\hline \multicolumn{2}{c|}{ Inglês } & \multicolumn{2}{c}{ Espanhol } & \multicolumn{2}{c}{ Português } \\
\hline Legenda & Dublagem & Legenda & Dublagem & Legenda & Dublagem \\
\hline $\begin{array}{c}\text { You have to } \\
\text { let it go }\end{array}$ & $\begin{array}{c}\text { You have to } \\
\text { let snow }\end{array}$ & $\begin{array}{c}\text { Tienes que } \\
\text { dejarlo ir }\end{array}$ & $\begin{array}{c}\text { Tienes que } \\
\text { dejarte } \\
\text { nieve }\end{array}$ & Livre estou & Livre estou \\
\hline A-MEI-ZING! & A-MEI-ZING! & $\begin{array}{c}\text { iMei con M } \\
\text { de } \\
\text { Maravillosa! }\end{array}$ & $\begin{array}{c}\text { iMei con M } \\
\text { de } \\
\text { Maravillosa! }\end{array}$ & A-MEI!!! & A-MEI!!! \\
\hline
\end{tabular}

O filme apresenta uma canção original, tida como a principal e mais marcante, chamada "Let it go", traduzida em espanhol como "Libre soy" e em português como "Livre estou". Na frase utilizada pela personagem no jogo, em inglês existe a referência direta à canção do filme, bem como em português. Porém, em espanhol, optou-se por traduzir a sentença literalmente, anulando a referência ao filme. A tradução em espanhol "Tienes que dejarlo ir" foge da proposta inicial de referir-se ao clássico da Disney e, mesmo que semanticamente represente o TF, neutraliza a fala. Segundo González (2016), essa neutralização traz o elemento cultural sem alterá-lo, sem acrescer marcas culturais da língua alvo ou de cultura amplamente difundida. Com essa mesma personagem, em outra sentença, pode-se observar que as equipes de localização encontraram dificuldade para traduzir um trecho com recurso estilístico que agrega um item lexical ao nome da personagem.

O jogo de palavras com o nome da personagem, Mei, foi aproveitado na versão em língua portuguesa do jogo, onde "A-MEI-ZING" se tornou "A-MEI" em português. Porém, em espanhol, esse jogo de palavras não foi possível devido a imposições do próprio sistema linguístico. Então, optou-se por compensar, em vez de uma única palavra, que tivesse o nome Mei, utilizando a frase con $M$ de maravillosa. Outro exemplo de jogo de palavras pode ser visto no Quadro 8.

Quadro 8 - Exemplos de falas da personagem Pharah nos três idiomas e localizado no português

Personagem: Pharah

\begin{tabular}{c|c|c|c|c|c}
\hline \multicolumn{2}{c|}{ Inglês } & \multicolumn{2}{c|}{ Espanhol } & \multicolumn{2}{c}{ Português } \\
\hline Legenda & Dublagem & Legenda & Dublagem & Legenda & Dublagem \\
\hline
\end{tabular}

${ }^{20}$ Cf. https://frozen.disney.com/ . Acesso em: 01 jun. 2018. TradTerm, São Paulo, v.32, dezembro/2018, p. 116-137 


\begin{tabular}{c|c|c|c|c|c}
\hline $\begin{array}{c}\text { Play nice, } \\
\text { play Pharah }\end{array}$ & $\begin{array}{c}\text { Play nice, } \\
\text { play Pharah }\end{array}$ & $\begin{array}{c}\text { Juega bien, } \\
\text { juega con } \\
\text { Pharah }\end{array}$ & $\begin{array}{c}\text { Juega bien, } \\
\text { juega con } \\
\text { Pharah }\end{array}$ & $\begin{array}{c}\text { Faça como a } \\
\text { Pharah faria }\end{array}$ & $\begin{array}{c}\text { Faça como a } \\
\text { Pharah faria }\end{array}$ \\
\hline
\end{tabular}

Nessa situação, existe um jogo de palavras que traz uma sonoridade peculiar na oração da personagem em inglês, que é facilmente notada, pois o game é todo dublado. Em espanhol a tradução foi literal, seguindo a mesma proposta do texto na língua fonte. Contudo, na versão brasileira do game, além do jogo de palavras, a sonoridade da frase apresentada inicialmente, foi mantida. Segundo Scholand (2002), essa é a função da localização, já que o produto localizado visa, dentre outros, transparecer uma roupagem mais nacional.

Outro exemplo rico no uso de localização de falas, e o do personagem Torbjörn, cuja tradução para o português faz alusão ao poema "se urubu cantasse", de JL semeador, que diz "Se urubu cantasse viveria preso em gaiola. Foi isso que um amigo me disse com um jeito todo gabola..." 21. Embora o poema possa não ser tão difundido, a expressão é e cumpre com sua função de localização.

Quadro 9 - Exemplos de falas do personagem Torbjörn nos três idiomas e localizados no português

\begin{tabular}{c|c|c|c|c|c}
\hline \multicolumn{2}{c}{ Inglês } & \multicolumn{2}{c}{ Espanhol } & \multicolumn{2}{c}{ Português } \\
\hline Legenda & Dublagem & Legenda & Dublagem & Legenda & Dublagem \\
\hline $\begin{array}{c}\text { A chicken } \\
\text { out of } a \\
\text { feather }\end{array}$ & $\begin{array}{c}\text { You're } \\
\text { making } a \\
\text { chicken out } \\
\text { of a feather }\end{array}$ & $\begin{array}{c}\text { Una gallina } \\
\text { de una } \\
\text { pluma }\end{array}$ & $\begin{array}{c}\text { Estás } \\
\text { haciendo } \\
\text { una gallina } \\
\text { de una } \\
\text { pluma }\end{array}$ & $\begin{array}{c}\text { Se urubu } \\
\text { cantasse }\end{array}$ & $\begin{array}{c}\text { Se urubu } \\
\text { cantasse eu } \\
\text { tinha dois } \\
\text { na gaiola }\end{array}$ \\
\hline $\begin{array}{c}\text { Let's not } \\
\text { buy the pig }\end{array}$ & $\begin{array}{c}\text { Let's not } \\
\text { buy the pig } \\
\text { while it's } \\
\text { still in the } \\
\text { bag }\end{array}$ & $\begin{array}{c}\text { No } \\
\text { compremos } \\
\text { el cerdo }\end{array}$ & $\begin{array}{c}\text { No } \\
\text { compremos } \\
\text { el cerdo } \\
\text { mientras } \\
\text { aún está en } \\
\text { la bolsa }\end{array}$ & Não contem \\
com o ovo & $\begin{array}{c}\text { Não contem } \\
\text { com o ovo } \\
\text { que a }\end{array}$ \\
galinha não \\
pôs.
\end{tabular}

Conforme Quadro 9, vê-se que a tradução em espanhol seguiu a linha do TF, apresentando um texto traduzido literalmente em sua essência. $\mathrm{Na}$ versão nacional, por sua vez, permitiu-se adaptar as expressões por sentenças utilizadas no território brasileiro. O primeiro exemplo do Quadro 9, "You're making a chicken out of a feather" é traduzido por "Se urubu cantasse eu tinha dois na gaiola", e no segundo exemplo do mesmo quadro, "Let's not buy the pig while it's still in the bag" foi traduzido por "Não contem com o ovo que a galinha não pôs".

Em ambos os casos, expressões idiomáticas nas quais há a presença de animais sofrem alterações em prol da fluência do texto e da imagem que as metáforas trazem em cada cultura. Além disso, preocupam-se mais com a

${ }^{21}$ Disponível em: http://www.recantodasletras.com.br/poesias/3558768. Acesso em: 13 jun. 2017

TradTerm, São Paulo, v.32, dezembro/2018, p. 116-137

www.revistas.usp.br/tradterm 
mensagem que com a literalidade da expressão. Por isso, em português, galinha virou urubu para adequar-se a um ditado - e poema - nacional, e porco virou galinha com o mesmo propósito.

Em outros casos, o uso de um referente cultural popular nacional confere ao texto a característica nacional almejada pelos tradutores/localizadores, conforme demonstrado no exemplo do Quadro 10.

Quadro 10 - Exemplos de falas da personagem Tracer nos três idiomas e localizado no português

Personagem: Tracer

\begin{tabular}{c|c|c|c|c|c}
\hline \multicolumn{2}{c|}{ Inglês } & \multicolumn{2}{c|}{ Espanhol } & \multicolumn{2}{c}{ Português } \\
\hline Legenda & Dublagem & Legenda & Dublagem & Legenda & Dublagem \\
\hline $\begin{array}{c}\text { She shoots, } \\
\text { she scores }\end{array}$ & $\begin{array}{c}\text { She shoots, } \\
\text { she scores }\end{array}$ & $\begin{array}{c}\text { Estoy que } \\
\text { ardo }\end{array}$ & $\begin{array}{c}\text { Estoy que } \\
\text { ardo }\end{array}$ & $\begin{array}{c}\text { Ela chuta e } \\
\text { é gol }\end{array}$ & $\begin{array}{c}\text { Ela chuta e } \\
\text { é gol haha }\end{array}$ \\
\hline
\end{tabular}

A inserção do futebol na fala da personagem é um exemplo de domesticação, cujo apelo popular é bastante característico. Em espanhol se faz uma referência ao game em si, que diz respeito a como a personagem fica quando uma grande pontuação é obtida, seja eliminando adversários, transportando a carga ou defendendo um objetivo, ou seja, "em chamas", que é a descrição do estado de conquista do jogador. Já em português, o estado do personagem é comparado ao estado de um jogador quando faz um gol.

\section{Considerações finais}

O estudo aqui apresentado se propôs a cotejar dados referentes à localização das falas (legenda e dublagem) do jogo Overwatch. Nesse sentido, observaram-se diferenças referentes à localização nas versões em espanhol e em português, tanto quantitativa como qualitativamente, apontando para maior localização da versão brasileira, mais próxima da cultura e do público alvos.

Da mesma forma, também foram encontradas diferenças quantitativas entre as modalidades de tradução (legenda e dublagem) nos diferentes idiomas e entre eles. A legenda e a dublagem, em espanhol, possuem praticamente o mesmo número de formas (tokens), sendo que em inglês e em português, a dublagem possui mais formas que a legenda. Esse dado é corroborado quando da análise qualitativa, cujas informações mostram maior uso de expressões idiomáticas e traços característicos da cultura alvo na versão brasileira comparada com a versão em espanhol. Igualmente, pode-se afirmar que a domesticação é um dos procedimentos técnicos de tradução mais utilizados na versão brasileira, e que talvez isso seja um traço idiossincrático da tradução de games no Brasil, muito embora isso não possa ser generalizado somente com base neste estudo.

Nesse sentido, é necessário que estudiosos de tradução se debrucem sobre o tema, já que o campo é vasto e fértil para pesquisa, além do apelo mercadológico que ele comporta, tanto para as empresas de entretimento, 
como para a inserção de tradutores nesse mercado. Dessa forma, sugere-se a compilação de um corpus maior, com diferentes jogos e diferentes prismas de análise, para então encontrar padrões (ou a ausência deles) na tradução/localização de games do Brasil.

\section{Referências bibliográficas}

Baker, M.; Saldanha, G. Routledge Encyclopedia of Translation Studies. New York: Routledge, 2009. p. 661.

Berber Sardinha, T. Linguística de Corpus. Barueri-SP: Manole, 2004

ColetI, B.; MotTA, L. A Localização de Games no Brasil - Um ponto de vista prático. In-traduções: Games e Tradução, v. 0, n. 5, nov. 2013, p.112.

HolmES, J. The name and nature of translation studies. In: VENUTI, L. (ed.) The Translation Studies Reader, $2^{\mathrm{a}}$ ed., London/New York: Routledge, 2004, p. 180-192.

MATOS, P. O nerd virou cool: identidade, consumo midiático e capital simbólico em uma cultura juvenil em ascensão. In: Estudos Interdisciplinares da Comunicação do XVI Congresso de Ciências da Comunicação na Região Sudeste, 2011, São Paulo. Disponível em: <http://www.intercom.org.br/papers/regionais/sudeste2011/resumos /R24-1149-1.pdf>. Acesso em: 15 maio 2017.

MÉNDEZ GonZÁLEZ, R. Localización y Cultura: Comprender los Videojuegos como Referentes Culturales. Entreculturas, v. 7-8, 2016, p. 741-749.

MÉNDEZ GonzÁLEZ, R. Localización de Videojuegos: Paratextos Materiales e Icónicos. Scientia Traductionis, n. 15, 2014, p. 77-93. Disponível em: <https: //periodicos.ufsc.br/index.php/scientia/article/view/198 0-4237.2014n15p77>. Acesso em: 13 abr. 2017.

MIRoIR, J. C. A "otimização dos mecanismos de busca" (SEO) como ferramenta de coleta automatizada de documentos para elaboração de corpora. In: Anais do EBRALC 2015 \& ELC 2015 [=Blucher Social Science Proceedings, n.3, v.2]. São Paulo: Blucher, 2016, p. 48-78.

MundaY, J. The Routledge Companion to Translations Studies. New York: Routledge, 2009.

Pernas, M. Paseo por la localización de un videojuego. Tradumàtica, n. 5, 2007, p. 1-6, Disponível em: <http://www.fti.uab.cat/tradumatica/revista>. Acesso em: 13 abr. 2017.

Roscoe-Bessa, C.; AquINo, J.; Borges, R. O Local e o Universal: Cosméticos e Comestiveis. 1a ed. Brasil: Editora 7 Letras, 2015.

SCHOLAND, M. Localización de videojuegos. 1. ed. [S.l.]: La Localització, 2002. Pp. 1-9. Disponível em: 
<http://www.fti.uab.es/tradumatica/revista/articles/mscholand/msc holand.pdf>. Acesso em: 13 abr. 2017.

SouzA, R. Venuti e os Videogames: o conceito de domesticação/estrangeirização aplicado à localização de games. In: Traduções, v. 8,2013, p. 51-69. Disponível em: <http://incubadora. periodicos.ufsc.br/index.php/intraducoes/article /view/2519/3141>. Acesso em: 13 abr. 2017.

SousA, J. F.; GOBBI, M. C. Geração Digital: uma reflexão sobre as relações da "juventude digital" e os campos da comunicação e da cultura. Revista GEMInIS, [S.l.], v. 5, n. 2, p. 129-145, jul. 2014. Disponível em: <http://www.revistageminis.ufscar.br/index.php/geminis/article/vie w/193>. Acesso em: 12 dez. 2018.

Willian, J.; Chesterman, A. The Map: a begginer's guide to doing research in translation studies, Manchester: St. Jerome Publishing, 2007.

Recebido em: $11 / 06 / 2018$

Aceito em: $11 / 12 / 2018$

Publicado em dezembro de 2018 